\title{
MÁRIO DE SÁ-CARNEIRO: INDÍCIOS DE UM MITO, INDÍCIOS DE UM CORPO
}

\author{
Matheus Nogueira Schwartzmann* \\ Universidade Estadual Paulista Júlio de Mesquita Filho
}

\begin{abstract}
Resumo: O presente artigo tem por objetivo propor uma leitura de sobrevoo de alguns elementos da obra de Mário de Sá-Carneiro, buscando apontar, primeiramente, como a sua dimensão mítica, cultivada desde as primeiras edições de sua obra, marcou profundamente a leitura que dela se fez. Nesse sentido, trataremos do seu suicídio, retomado e reafirmado por nomes como Fernando Pessoa, José Régio, Casais Monteiro, por exemplo, e de como esse tema contribuiu para a cristalização do seu mito. Em um segundo momento, levando em consideração determinados temas e figuras que podem ser apreendidos nos textos de SáCarneiro, indicaremos outros caminhos de leitura, buscando em poemas, cartas e algumas das suas narrativas elementos que permitam entrever na sua escrita a presença do seu corpo. E é a descrição desse corpo, que repropõe noções como feminino e masculino, que nos parece ser aquilo que devemos considerar como inovador na sua poesia, na medida em que seria justamente uma das suas marcas de modernidade.
\end{abstract}

Palavras-chave: Mário de Sá-Carneiro. Mito. Feminilidade. Corpo.

\section{Sá-Carneiro em carta(z)}

De que me vale sair, se me constipo logo? / E quem posso eu esperar, com a minha delicadeza?... / Deixa-te de ilusões, Mário. Bom édredon, bom fogo — / E não penses no resto. É já bastante, com franqueza...

Mário de Sá-Carneiro, em “Caranguejola” (1996, p. 133).

Mário de Sá-Carneiro (1890-1916), ao contrário de muitos de escritores, teve o privilégio de receber em vida o reconhecimento por sua obra. Privilégio maior, talvez, foi o de ser reconhecido por outro escritor de grande estatura, o seu contemporâneo e amigo próximo, Fernando Pessoa (1888-1935) - reconhecimento este que teve suas consequências, como buscaremos mostrar.

\section{Esta obra está licenciada sob uma Creative Commons - Atribuição 4.0}

\footnotetext{
* Doutor em Linguística e Língua Portuguesa (2009) e mestre em Estudos Literários (2005) pela UNESP, é professor do Departamento de Linguística da Faculdade de Ciências e Letras da Unesp, câmpus de Assis (SP) e do Programa de Pós-Graduação em Linguística e Língua Portuguesa da Faculdade de Ciências e Letras da Unesp, câmpus de Araraquara (SP). Tem experiência na área de Linguística, especialmente na sua interface com os Estudos Literários, com ênfase na Semiótica de linha francesa, interessando-se pelos estudos do discurso, pelo estudo das formas de vida e da identidade, pelo estudo dos gêneros em abordagem semiótica, com especial destaque ao gênero epistolar e à poesia. E-mail: <matheusns@assis.unesp.br>.
} 
Embora o alcance da obra do poeta de Mensagem (1934), como bem se sabe, seja muito mais vasto, cem anos após a morte de Sá-Carneiro, ele permanece como um dos maiores poetas do século XX, sua obra tendo sido já objeto de estudos de pesquisadores espalhados por todo o mundo. Em muitos desses estudos há uma constante que sempre nos chamou a atenção: são trabalhos que propõem uma leitura da obra de Sá-Carneiro que acabam (re)construindo o próprio sentindo de sua obra - e o próprio sentido de sua vida - chegando por vezes a alterá-la(s).

Isso ocorre na medida em que se sobressaem certos elementos de caráter biográfico com o tema do suicídio no centro das discussões - e, não menos frequentemente, a necessidade de se estabelecer relações de "parentesco" entre o autor e determinadas escolas literárias.

Se já antes de se descobrirem suas primeiras cartas, seus textos eram considerados confessionais - A confissão de Lúcio (1991 [1995]) contribuindo largamente para esse efeito de sentido - depois da publicação de sua correspondência com Fernando Pessoa, no final dos anos 1950, seus textos foram quase que totalmente associados à sua vida. Esse fenômeno tem algumas explicações: os universos temático e figurativo, bem como os valores manifestados em sua correspondência são similares, se não por vezes idênticos, aos de seus textos literários. Também quase a totalidade de seus textos são enviados para Pessoa, comentados e/ou citados nas cartas, o que facilitou a detecção de trechos, de formas identitárias, de dramas, de cenas e narrativas muitas vezes comuns à obra e à correspondência. Além disso, as poesias e narrativas de Sá-Carneiro foram sempre datadas e assinadas, em um gesto repetido e contínuo do autor que aproximou ainda mais os seus textos das suas cartas, impregnando-os do efeito de "sinceridade" inerente ao gênero epistolar (SCHWARTZMANN, 2009).

Foi, naturalmente, com base na pretensa sinceridade emanada de sua obra que muitos leitores e pesquisadores, ao dela falarem, buscaram, de fato, tratar principalmente do poeta, do próprio Mário, sujeito-histórico, em leituras frequentemente de caráter psicológico, que por si só também fortaleceram um imaginário interpretativo que tem como base o próprio imaginário literário que ele concebeu para sua obra. E é disso que trataremos a seguir.

\section{A persona(gem) mítica e a ilusão confessional}

(- Por isso a sensação em mim fincada há tanto / Dum grande património algures haver perdido; / Por isso o meu desejo astral de luxo desmedido - / E a Cor na minha Obra o que restou do encanto...)

Mário de Sá-Carneiro, em “O Lord” (1996, p. 121). 
O efeito de sentido de autobiografia ${ }^{1}$, que não raro se desprende das cartas, terminou por contaminar outros textos, sendo evidente que a morte anunciada, encenada e cumprida tenha ajudado a fazer com que sua escrita adquirisse uma espessura quase ontológica, na medida em que nas cartas se desenhou uma narrativa de desesperança que tem um fim determinado, com dia e hora marcados.

Na sua correspondência, narra-se, pois, a confissão de uma identidade que, segundo a leitura que se estabeleceu, de tão humana, de tão enternecida de si mesma, materializa-se em um corpo sensível que nos dá a impressão "real" de ter realmente vivido. No entanto, pouco há nas cartas sobre os dias que passava como jovem cidadão português "autoexilado" em Paris: são raríssimas, na sua correspondência com Fernando Pessoa, menções pontuais sobre sua rotina, sobre "o sustento do corpo, da vida cotidiana, das coisas banais e inferiores" (SCHWARTZMANN, 2009, p. 225), como costumava dizer Sá-Carneiro. Quando algum “acontecimento" era digno de nota, surgia já "literatizado", sempre ocultado por metáforas e figuras comuns à sua poesia, que já o distanciavam de uma realidade tangível. Isto é, embora tenham sido lidas como transcrição e/ou tradução de um estado psíquico, como retrato de um cotidiano convulsivo, suas cartas não eram registros exatos de uma vida, mas a experiência literária que dessa vida resultava. Em uma de suas últimas cartas, diz Sá-Carneiro:

Vivo há 15 dias uma vida como sempre sonhei: tive tudo durante eles: realizada a parte sexual, enfim, da minha Obra - vivido o histerismo do seu ópio, as luas zebradas, os mosqueiros roxos da sua Ilusão (SÁ-CARNEIRO, 2004, p. 373-374).

Nada aí parece ter lugar na realidade porque são muito mais elementos de um mundo poético do que de um mundo real possível. Os 15 dias não são detalhados, não se sabe realmente o que houve e as frases ecoam outras cartas, escritas em outros momentos, assim como nelas encontramos fragmentos dos próprios textos narrativos e poéticos que escreve. Quanto às cartas, pode-se citar, por exemplo, carta de 13 de julho de 1914, dois anos antes, em que diz:

\footnotetext{
Passei na vida literária, creio, uma rapariga estrangeira, esguia, pintada, viciosa, com muito gosto para se vestir bizarramente - pelo menos - e para dispor orquídeas em jarras misteriosas, em esquisitas talhas do Japão - gulosa de morangos e champanhe, fumando ópios, debochada - ardendo loucamente. E se assim é, se não me engano: eu fui o que quis: a minha obra representa zebradamente entre luas amarelas aquilo que eu quisera ser fisicamente (SÁ-CARNERIO, 2004, p. 190,
}

\footnotetext{
1 Nesse sentido, há já alguns estudos da obra de Sá-Carneiro (Cf. SOUZA NETO, 2015; SILVA, 2012 e FERREIRA, 2011, por exemplo) que a tomam como exercício de autoficção, na esteira das propostas de Serge Doubrovsky (1977). Embora não caminhemos nessa direção, acreditamos que tal abordagem pode ser muito produtiva.
} 
grifo nosso).

Aquilo que foi ou quis ter sido, aquilo que vive ou viveu, tudo é construído como evidente efeito literário. O histerismo sintetizado na frase de 1916 estava já na sua forma analítica na carta de 1914, desdobrado e expandido na sequência de figuras do feminino tão caras a Sá-Carneiro - e às quais nos voltaremos mais adiante. A representação zebrada de sua obra, a figura da lua, tudo se repete. E assim o é por toda a correspondência. Quanto aos poemas e às narrativas, as luas, o roxo, e a ilusão são imagens frequentes, do mesmo modo como a figura da "rapariga estrangeira", "debochada", "ardendo loucamente" nos faz pensar, imediatamente, na americana ruiva d'A Confissão, bem como nas suas "bailadeiras" (SÁCARNEIRO, 1991, p. 11) parisienses, especialmente se levarmos em conta a polissemia de "ardendo": do desejo às chamas.

Além desse controle sobre a sua obra, que cita ou parafraseia com frequência, na sua correspondência Sá-Carneiro narra uma história com começo, meio e fim, tal qual o narrador de uma de suas novelas, vendo-a de fora, conhecendo o (seu) próprio enredo. Tomadas então como um conjunto significante global e coeso, as cartas bem mostram que a personagem SáCarneiro nelas inscrita "ilude" seu leitor, pois, ao construir uma vida frágil, que busca de algum modo preservar (atapetando-a, vestindo-a bizarramente de pedras preciosas, de luxo), preserva e constrói, na verdade, uma Obra. A consciência do valor literário e do alcance de sua escrita epistolar aparece já em 1914, em carta do dia 20 de julho, na qual concorda com Fernando Pessoa: "Você tem razão, que novidade literária sensacional o aparecimento em 1970 da Correspondência inédita de Fernando Pessoa e Mário de Sá-Carneiro — publicada e anotada por... (perturbador mistério!)" (SÁ-CARNEIRO, 2004, p. 196).

Assumindo assim o domínio da narrativa epistolar que alinhava carta a carta, SáCarneiro constrói o seu sacrifício, a sua renúncia à vida, enquanto metáfora do aniquilamento da identidade, enquanto percurso de ascensão e queda ${ }^{2}$ que, graças ao seu suicídio, será revestido de sinceridade.

Para além das cartas, a sua proximidade com Fernando Pessoa contribuiu também em muito para essa leitura, na medida em que Pessoa, ele mesmo travestido de argumento de autoridade, reforçava a ligação entre vida e obra na escrita de Sá-Carneiro, e entre a sua escrita e o seu ato confessional. Em carta a João Gaspar Simões, de 10 de janeiro de 1930,

\footnotetext{
${ }^{2}$ É o percurso traçado, por exemplo, ao longo dos 12 poemas de Dispersão (SÁ-CARNEIRO, 2005), em que se pode ler a "Partida" (primeiro poema) do sujeito, a sua "Dispersão" (sexto poema) e "A Queda" (último poema) final. Nas cartas teríamos, analogamente, a partida do sujeito para Paris, sua dispersão diante dos seus desejos de vida e de morte, e a sua queda final, no gesto suicida, eternizada no último bilhete.
} 
Pessoa chega mesmo a dizer que "felizmente, em todo o sentido, de todos os sentidos, o SáCarneiro não teve biografia: teve só génio. O que disse foi o que viveu” (PESSOA, 1982, p. 40). Se o disse com seriedade ou apenas pelo gracejo de um chiste literário ${ }^{3}$, fingido, pouco importa hoje: a pedra angular do mito estava aí assentada e a personagem Mário de SáCarneiro estava então devidamente construída. Dois grandes pilares da crítica literária portuguesa, João Gaspar Simões e Adolfo Casais Monteiro, por exemplo, acabam por repetir e eternizar essa imagem.

Gaspar Simões (1971, p. 128-130), incorrendo talvez no mesmo gesto de sincretizar numa única esfera autor, homem e personagem, diz que:

Nesta avidez de encontrar um suporte para a vida, uma personalidade una e consequente [...] Sá-Carneiro hesitou, mas apenas momentaneamente. Logo viu chegar um meio de salvação. Não podia vacilar por mais tempo. A sua personalidade escoava-se por entre os dedos da vontade? [...] Havia um recurso. Deixá-la ser como era: evitando-a, fugindo-lhe também e, para suprir a sua falta, confiando-se a uma outra personalidade. O problema estava, pois, resolvido desde que Sá-Carneiro criasse um "duplo" - uma personalidade de ficção. [...] Por isso, quando julgamos ir encontrá-lo, desesperado ou resignado, torturado ou sereno, confessando-se na sua obra - apenas encontramos dele [...] um "duplo" ideal.

Alinhando-se à tradição psicologista da qual falamos, Gaspar Simões busca analisar o Mário, não o poeta, reduzindo a obra à crise psicológica do autor. Sua análise é lúcida na medida em que imaginamos que ele trata do "eu-lírico" dos poemas e do desejo que consome essa identidade que vislumbra, em devir, ser uno e duplo. Entretanto, Gaspar Simões verá nessas imagens indícios de uma sinceridade, no sentido mais vulgar do termo, parece-nos, uma sinceridade plena que revela assim aspectos de uma personalidade torturada que busca na sua confisssão, na sua criação, salvar-se de si mesmo.

Para Adolfo Casais Monteiro (1933, p. 148), o poeta era, mesmo antes da divulgação de suas cartas, "aquela criatura frágil que a vida, para a qual não tinha sido feita, amarfanhou e aniquilou". As impressões de Gaspar Simões e Casais Monteiro ressoam, ainda, na visão de António Quadros (1947, p. 266), para quem Sá-Carneiro: “foi um torturado, um homem que andava na vida à procura do seu destino - sem nunca o ter encontrado [e que tanto] em prosa, como em poesia, [...] é sempre o mesmo: inquieto, rindo amargamente de si próprio, buscando a todo o momento novas direções."

Embora se tenha buscado na Obra encontrar o reflexo da Vida, François Castex, um

\footnotetext{
${ }^{3}$ Não podemos aqui esquecer de mencionar algumas palavras de Fernando Pessoa a respeito de Vicente Guedes, no seu Livro do desassossego (1990) que ecoam, de modo bastante evidente, o que disse na carta a Gaspar Simões: "Este livro é a biografia de alguém que nunca teve vida. De Vicente Guedes não se sabe nem quem era, nem o que fazia [...] Este livro não é dele: é ele" (PESSOA, 1990, p. 65).
}

Anu. Lit., Florianópolis, v. 21, n. 2, p. 56-78, 2016. ISSNe 2175-7917 
dos grandes especialistas no poeta, assume claramente, ainda que inconsolado, a impossibilidade de se alcançar a Vida de Sá-Carneiro por essa via, algo que, para ele, seria fundamental. Castex, longe de criticar o biografismo, o incita:

Apesar de todo o mal que se possa ter dito do "biografismo", às vezes é preciso, com toda a razão, admitir que existe uma ligação entre o homem e a obra mesmo se essa ligação ainda permanece misteriosa [...] Partindo de um texto seguro e confiável é preciso buscar todos os meios de compreender o que Sá-Carneiro quis nos dizer. Esse trabalho só pode ser realizado por uma equipe de pesquisadores advindos de diversos horizontes da crítica literária. Mas seria talvez um projeto muito ambicioso? (CASTEX, 1986, p. 333).

Na mesma direção vai a publicação da Biblioteca Nacional de Lisboa (1990) comemorativa dos cem anos do nascimento de Sá-Carneiro, em que foram reunidas reproduções de textos manuscritos, fotografias, trabalhos artísticos e alguns estudos sobre a sua obra. Esses estudos ${ }^{4}$ são exemplares de um modelo - ou mesmo de um estilo - crítico, marcado por elementos "históricos" e "biografistas", muito semelhante àquele levado a cabo pelos colaboradores da Presença (1927-1940), em especial por José Régio. Tais estudos indicam nitidamente a intenção de não apenas enquadrar a obra de Sá-Carneiro a um período literário específico (simbolismo ou futurismo, por exemplo), como também de resgatar elementos de sua vida que acabam sendo colocados fora de um contexto de obra, dando apenas sentido à biografia do autor.

Essas diversas leituras da obra de Sá-Carneiro, de Casais Monteiro até a obra da BNL, para além de encontrar semelhanças com o seu percurso de vida, parecem muitas vezes tentar estabelecer uma relação de verossimilhança entre vida e obra - que acaba lida como manifestação teatralizada de sua psique, de sua identidade. Foi esse exercício de crítica que contribuiu para a criação de uma espécie de macronarrativa em que Mário de Sá-Carneiro é a personagem principal, personagem que, fragilizada e triste, se confessa antes de partir.

Mas há aí, talvez, algum exagero, uma vez que esse ponto de vista tem cegado outras miradas (ou outras miragens) sobre a obra de Sá-Carneiro - e não estamos sozinhos nessa constatação. O escritor e pesquisador Fernando Paixão (2003), por exemplo, em estudo sobre a poética de Sá-Carneiro, afirma que:

É comum a obra de Sá-Carneiro estar associada a interpretações de fundo psicológico. Não por acaso, o fundamento confessional de sua poesia vem desnorteando a visão crítica, adepta muitas vezes de abordagens simplistas,

\footnotetext{
${ }^{4}$ Os títulos desses estudos são os seguintes: “Itinerário Humano de Mário de Sá-Carneiro”, por Maria Aliete Galhoz; "Algumas marcas simbolistas na poesia de Sá-Carneiro", por Paula Mourão; "Sá-Carneiro, Aquilino Ribeiro e o futurismo", por Dieter Woll; "Os olhos Futuristas", por Fernando Cabral Martins e "Mário de SáCarneiro ou a reposição permanente dos enigmas”, por Ana Nascimento Piedade.
} 
circunscrevendo o âmbito de seus versos aos termos de um "egocentrismo doentio" e outros conceitos igualmente duvidosos (PAIXÃO, 2003, p. 59).

Fernando Cabral Martins, em O Modernismo em Mário de Sá-Carneiro (1997), também levanta a questão, tendo sido ele provavelmente um dos primeiros pesquisadores a colocar em xeque essa característica que a obra de Sá-Carneiro adquiriu com o passar dos anos. Para ele, o biografismo gerou um status de mito ao redor da figura de Sá-Carneiro, certamente favorecido pelas primeiras leituras de sua obra que colocaram em evidência a tragicidade que envolvia a sua imagem, relegando a um segundo plano a própria obra. Ao tratar desse fenômeno, que chamou de ficcionalização do autor, Martins aponta para o que seria esse mito:

É um dos modos pelos quais o leitor dá sentido ao texto que lê, reduzindo a constitutiva indeterminação semântica do literário aos moldes da sua experiência própria. Se se considerar que o leitor escreve a sua leitura, nos casos, por exemplo, do historiador e do crítico, tal ficcionalização do autor pode ganhar contornos concretos, organizados segundo uma lógica narrativa. Poderemos, então, falar num mito do autor - quando a sucessão histórica das interpretações dos seus textos segue sempre os mesmos trâmites, parecendo partir de um certo número de dados preconcebidos (MARTINS, 1997, p. 15).

Ainda em Martins (1997, p. 15-16), temos dois exemplos que demonstram que as considerações sobre Sá-Carneiro e sua obra possuem, independentemente da origem, uma mesma estrutura, porque já partem dos mesmos dados pré-construídos. O primeiro exemplo que Martins nos dá foi retirado do "monumental Guide to Modern World Literature", de 1973, e o segundo, de um suplemento literário do jornal francês Libération, de 20 de dezembro de 1990. No primeiro caso, define-se o livro de poemas Dispersão como sendo "the dispersion of his own personality [...]. In one of the poems he predicts his death in Paris [...]"5. No segundo, que é na verdade a apresentação de uma antologia de poemas de Sá-Carneiro traduzidos para o francês, há a referência a sua amizade com Pessoa, de quem é "presque le double" e são citadas as duas quadras do poema "Fim", acrescidas de "quelques jours plus tard, dans un hôtel parisien, il mettait son smoking et s'en allait avec un peu de strychnine".

Os exemplos colhidos por Martins parecem constituir um imaginário literário incontestável, que permaneceu intacto por duas décadas (de 1973 a 1990). Nesse imaginário, em que o biografismo reina absoluto, ao apresentar-se o poeta, vem à tona a sua relação com Fernando Pessoa, tido como o seu duplo, a noção de que os poemas são reflexo de sua

\footnotetext{
5 “A dispersão de sua própria personalidade [...] Em um de seus poemas, ele prevê sua morte em Paris" (tradução nossa).

6 "Quase o duplo"; "alguns dias depois, em um hotel parisiense, vestiu seu smoking e se matou com um pouco de estricnina" (tradução nossa).
} 
personalidade, o tema da amizade e, por fim, o suicídio, ponto culminante de sua obra/vida.

No Brasil, esse imaginário também se mantém intacto há décadas. Conforme indicamos em Schwartzmann (2005, p. 30-31), na Antologia Luso-Brasileira, de Wagner Ribeiro, de 1964, voltada a alunos do curso secundário, tem-se a citação do poema "Ápice" (RIBEIRO, 1964, p. 378). Publicado na íntegra, o poema recebe uma nota explicativa que destaca alguns dos seus versos: "é como a ideia de Norte, /Preconcebida, /Que sempre me acompanhou...". Buscando "desvendar o sentido dos versos", diz Ribeiro (1964, p. 378): “O poeta estava com uma ideia fixa que haveria de morrer no Norte”. Em seguida, cita o célebre verso de "Dispersão": "E sinto que a minha morte [...] Existe lá longe, ao norte"7. Na nota sobre o autor, Wagner Ribeiro, após situar Sá-Carneiro como um poeta da vanguarda, pertencente à geração de Orpheu, diz que: "Seus versos, produtos de alma inquieta e atormentada, de difícil leitura e, por vezes, incompreensíveis encerram, no entanto, fulgurações de gênio [...]. Foi grande amigo e confidente de Fernando Pessoa a quem escreveu poucos dias antes de seu suicídio" (RIBEIRO, 1964, p. 378).

Como nos parece evidente, sendo uma antologia para alunos do antigo curso secundário, a obra não tem como objetivo efetuar uma análise aprofundada de cada autor que apresenta, sendo, pelo contrário, apenas uma maneira de levar aos alunos um conhecimento mínimo que lhes possa dar uma ideia geral da obra e do significado de cada poeta, na direção de uma perspectiva geral da história da Literatura. Nesse sentido, o que se constrói a respeito de Sá-Carneiro é, novamente, um imaginário em que se tem um poeta revolucionário e genial, amigo íntimo de Fernando Pessoa, que em seus versos expunha uma alma "atormentada", e que acabou, justamente por essa razão, suicidando-se.

É também em Schwartzmann (2005, p. 32-33) que encontramos outro exemplo, razoavelmente banal, que permite que se veja o modo como Sá-Carneiro é ainda hoje apresentando ao grande público. Trata-se de uma das obras musicais da cantora e compositora brasileira, Adriana Calcanhoto. No ano 2000, em seu show Público, gravado posteriormente sob o mesmo título, a artista, antes de cantar um poema de Sá-Carneiro musicado por ela, fala, por aproximadamente dois minutos, de seu primeiro contato com a sua obra e apresenta

\footnotetext{
${ }^{7}$ Em carta de 03 de maio de 1913, Sá-Carneiro diz a Fernando Pessoa: "Que quer dizer isso? Parece uma profecia... Por que a escrevi eu? Como é que de súbito me surgiu essa ideia de Norte, duma cidade do Norte que eu, depois, procurando, vejo que não pode ser outra senão S. Petersburgo?... [...] Depois de composta a poesia vi que ela era sincera, que encerra talvez um canto do meu estado de alma. Pelo menos, creio-o" (SÁ-CARNEIRO, 2004, p. 111-112). Como se vê, a grande capital não era Paris, uma vez que era em Paris que Sá-Carneiro escrevia seus poemas. O efeito de sinceridade que aqui sempre se quis encontrar era, como sempre, "literatura", no sentido que Sá-Carneiro dava ao termo. Quanto a isso, ver "A sinceridade fiduciária", em Schwartzmann (2009, p. 205-210).
}

Anu. Lit., Florianópolis, v. 21, n. 2, p. 56-78, 2016. ISSNe 2175-7917 
informações "que vão da superficialidade ao equívoco" (SCHWARTZMANN, 2005, p. 32), como podemos observar:

A próxima canção [...] é de um poeta português, contemporâneo de Fernando Pessoa, chamado Mário de Sá-Carneiro. E eu entrei em contato com a obra dele da seguinte forma: eu recebi um convite muito simpático da editora Nova Aguilar, isso em 1996, pra fazer uma noite de lançamento das obras completas do Mário de SáCarneiro no Brasil. E só uma pessoa como eu é capaz de topar uma empreitada dessa sem ter a menor noção de quem vem a ser o Mário de Sá-Carneiro e sua obra. Mário de Sá-Carneiro, um poeta português, contemporâneo de Fernando Pessoa, muito atormentado com isso, com o Fernando Pessoa, com a poesia em si, com a poesia dele, com o fato de ser gordinho, atormentado com a morte de uma tal maneira que aos 27 anos de idade não conseguiu esperar, então aos 27 anos de idade vestiu um smoking e se matou. Uma bichinha complicada com uma poesia não menos densa... e eu fiquei com esse osso pra roer lá em casa, as obras completas de Mário de SáCarneiro, para trabalhar. Então eu fiz, na livraria Argumento, uma noite de loucuras com os poemas de Mário de Sá-Carneiro, musiquei alguns, inclusive, e um deles é esse aqui que eu vou mostrar, que é um dos poemas mais conhecidos dele e se chama "O Outro" (CALCANHOTO, 2000, faixa 7).

No início de sua fala, a cantora situa o poeta Mário de Sá-Carneiro como sendo um contemporâneo de Fernando Pessoa, que resta na maior parte das vezes como paradigma e "lastro" de Sá-Carneiro. Ao dizer que seu contato com essa poesia se deu por um convite de uma editora, confirma ao mesmo tempo que não o conhecia, mas que há nele valor literário. Há também na sua fala ênfase na complexidade (uma dificuldade de leitura que está implícita) e na extensão da obra de Sá-Carneiro. Tendo já caracterizado a obra, passa para a descrição do próprio poeta e novamente afirma a sua proximidade com Fernando Pessoa, levando seu ouvinte a crer que entre eles havia mais que uma amizade ("muito atormentado [...] com o Fernando Pessoa"), o que seria, logo em seguida, comprovado na frase: "Uma bichinha complicada". Seguindo a linha do "atormentado", trata da relação de Sá-Carneiro com a poesia, com o seu peso e aparência e com a morte. É construída, como sempre, a figura do gênio revolucionário e suicida - porque complexado. Calcanhoto dá à figura do suicida ainda mais destaque quando revela que ele "vestiu um smoking e matou-se" 8 e termina por fundir poeta e obra, igualando-os por sua densidade e complexidade. Ora, o Sá-Carneiro descrito pela cantora não é impossível, mas é certamente estereotipado. A partir de um senso comum, formulado por uma leitura superficial da crítica sobre o autor, Calcanhoto ressalta uma ideia que, se verídica, jamais foi comprovada (a homossexualidade), faz de Sá-Carneiro um

\footnotetext{
${ }^{8}$ Schwartzmann (2005, p. 48) afirma que o único "a assistir à morte de Sá-Carneiro foi José Araújo, amigo seu em Paris que, exceção à regra, não era artista". Ainda segundo Schwartzmann, na carta que Araújo envia a Fernando Pessoa relatando a morte do amigo não há nenhuma menção ao modo como estava vestido. Essa referência apareceria em carta de Araújo ao pintor Jorge Barradas, em que diria, apenas "estava vestido, penteado" (SCHWARTZMANN, 2005, p. 48). Barradas é quem repete a história, acrescentando pela primeira vez o detalhe sobre a roupa de Sá-Carneiro: "sei que tratou das unhas, vestiu o seu melhor fato, penteou-se e ao acabar de o tomar, deitou-se [...] esperando a morte (MARTINS, 1997, p. 21).
}

Anu. Lit., Florianópolis, v. 21, n. 2, p. 56-78, 2016. ISSNe 2175-7917 
apêndice de Pessoa e ainda comete dois erros, um quanto à idade de Sá-Carneiro, que se matou aos 26 incompletos) e não aos 27 , e outro quanto ao título do poema, que não é "O Outro" e, sim, "7"9.

Ao recorrermos a esses dois exemplos, que se diferem dos de Martins principalmente pela ausência de autoridade científica dos comentadores da obra de Sá-Carneiro citados (Ribeiro e Calcanhoto), queremos mostrar do mesmo modo como ele o fez, a permanência no tempo desse estereótipo que contaminou a imagem e a obra de Mário de Sá-Carneiro. Entre a antologia dos anos 1960 e o CD dos anos 2000, temos um hiato de quatro décadas. Em ambos há o mesmo recorte, o mesmo psicologismo, a mesma ilusão biográfica que dá a Sá-Carneiro uma aura mítica.

Nessa direção, querendo demonstrar o modo como certas impressões se cristalizaram na leitura de sua obra, podemos mesmo chegar à recém-publicada Antologia, de Mário de SáCarneiro (2015), organizada por Cleonice Berardinelli. A antologia, contribuição inegável à leitura da obra de Sá-Carneiro e que naturalmente não pode ser comparada a impressões de senso comum tão genéricas como as últimas que acabamos de citar, segue, no entanto, por caminhos que nos levam também a uma ilusão mítico-biográfica. Certos títulos e subtítulos dos textos ensaísticos de Berardinelli, que acompanham a seleção de poemas, narrativas e cartas, evocam já os mesmos temas do abandono, do egoísmo, do suicídio, do mal-estar e do desajuste com sua autoimagem, que cristalizaram a dimensão confessional e autobiográfica de sua escrita: "Excluído por si mesmo"; "Um grande poeta, um 'pobre menino ideal"”; "A confissão de Lúcio - ou de Sá-Carneiro?” (SÁ-CARNEIRO, 2015, p. 8-10). Há, como se pode ver, uma força de permanência do mito, da personagem, da personalidade, da persona, enfim, que ultrapassa os textos.

\section{O suicídio como fim}

Todas essas leituras que têm como base o drama existencial de Sá-Carneiro, no entanto, ao buscarem dar conta da individualidade do poeta, acabam por unificar e achatar a sua obra, reduzindo muito vezes as leituras à sua ligação profunda com Fernando Pessoa, às imagens de artista genial, de poeta sincero e de suicida notável, sempre muito pouco à vontade com seu país natal, com o mundo e, principalmente, com seu corpo. Essas leituras fecharam portas para outros modos de ver a obra de Sá-Carneiro, obra que é evidentemente muito maior que ele mesmo.

\footnotetext{
9 "Eu não sou eu nem sou o outro, / Sou qualquer coisa de intermédio: / Pilar da ponte de tédio / Que vai de mim para o Outro" (SÁ-CARNEIRO, 1996, p. 80).
} 
Dentre os autores que conheceram ou se debruçaram sobre a obra de Sá-Carneiro, Fernando Pessoa foi um dos que mais contribuiu para a construção da personagem: para além do que disse nas suas cartas e nos seus textos críticos, a sua autoridade sobre a edição da obra de Sá-Carneiro e, principalmente, o modo como realinhou os últimos poemas do amigo contribuíram em muito para a gênese do mito que o recobriria. Conforme afirma Schwartzmann (2009, p. 175-176):

foi [...] o amigo íntimo quem organizou os últimos poemas de [...] Sá-Carneiro
dando-lhes um aspecto de conjunto narrativo coeso [...] reforçando o aspecto
"verossímil" e autobiográfico de sua literatura. Publicados na revista Athena 2, em
novembro de 1924, sob o título Últimos Poemas, em cuja introdução podia-se ler
"Morre jovem os que os deuses amam", os poemas "Caranguejola", "Último
Soneto', "O Fantasma" "El-Rei", "Aquele Outro" e "Fim" (título este dado pelo
próprio Pessoa à quadra que inicialmente não era titulada), davam forma [...] à
narrativa linear - de ascensão e queda [...] - de um suicida.

O modo como os Últimos poemas foram arranjados, não seguindo a ordem de produção por Sá-Carneiro e descontruindo até mesmo a obra Indícios de Oiro para fazer valer a sua unidade, contribuiu mais uma vez para a imagem do poeta derrotista que, por fim, suicida-se.

No poema "Caranguejola" (penúltimo poema de Indícios de Oiro), temos versos como "Deixa-te de ilusões, Mário", "Desistamos. A nenhuma parte a minha ânsia me levará" e "O menino dorme. Tudo o mais acabou", que conduzem para a constatação do estado depressivo e desertor de "Mário" - vocativo raro em toda a sua obra que acentua, de modo muito expressivo, o efeito de sinceridade e autobiografia. O poema "Último Soneto", último poema dos Indícios de Oiro, para o qual foi composto originalmente, ao suceder "Caranguejola", reforça o sentido, já pelo seu próprio título, de derrocada. N“O Fantasma”, tem-se a inadequação à vida: "O que farei na vida — o Emigrado/ Astral após que fantasiada guerra - / Quando este Oiro por fim cair por terra, / Que ainda é oiro, embora esverdinhado?".

O poema "El-Rei" abre-se para todo um conjunto de imagens funestas, que serão também acentuadas pela crítica, em especial por José Régio (1969), como mostraremos a seguir: "Quando chego — o piano estala agoiro, / E medem-se os convivas logo inquietos [...] Quem me convida mesmo não faz bem”.

Antecedendo o "Fim", “Aquele Outro" é o poema que marca em definitivo, com tintas fortes, uma imagem disfórica e disforme do poeta, preparando a sua morte carnavalizada: 
O dúbio mascarado, o mentiroso

Afinal, que passou na vida incógnito;

O Rei-lua postiço, o falso atónito;

Bem no fundo, o cobarde rigoroso...

Em vez de Pajem, bobo presunçoso.

Sua alma de neve, asco dum vómito...

Seu ânimo, cantado como indómito,

Um lacaio invertido e pressuroso...

O sem nervos nem ânsia, o papa-açorda...

(Seu coração talvez movido a corda...)

Apesar de seus berros ao Ideal.

O corrido, o raimoso, o desleal,

O balofo arrotando Império astral,

O mago sem condão, o Esfinge gorda... (SÁ-CARNEIRO, 1996, p. 141).

O poema "Fim", como o último poema de todos os poemas, reforça a previsão do suicídio, o desejo de morte e um certo gesto de derrisão do poeta: “Que o meu caixão vá sobre um burro / ajaezado à andaluza: / a um morto nada se recusa, / E eu quero por força ir de burro..."

\section{Teatro de sombras: 0 esfinge gorda}

Confesso-lhe que, infantilmente talvez, gostava muito de ver uma obra minha num palco. É que eu, no fundo, amo a vida.

Mário de Sá-Carneiro, em carta a Fernando Pessoa (SÁ-CARNEIRO, 2004, p. $143-$ 144).

No entanto, para além da narrativa de queda tão firmemente construída, parece-nos que é com José Régio que a imagem de Sá-Carneiro adquirirá o mais alto grau de teatralização, uma vez que a imagem que se estabeleceu sobre o poeta e que foi amplamente divulgada, foi aquela fixada por Régio em 1957, a partir já daquela criada por Pessoa, com a publicação da peça Mário ou Eu próprio - o Outro.

A peça, uma espécie de análise e, até mesmo, de paráfrase da obra de Sá-Carneiro, há o caso máximo da identificação entre vida e obra do poeta, a começar pelo título que é a citação direta de um de seus contos, "Eu próprio o outro", publicado originalmente em Céu em Fogo (1915).

Com Mário como a personagem principal, cuja morte é encenada, têm-se na peça, a todo momento, citações diretas e indiretas da obra de Sá-Carneiro, seja pelas falas das personagens (Mário e o Outro), seja pela temática e pela ambientação. Em 1957, a correspondência de Sá-Carneiro ainda não havia sido publicada, mas Régio demonstra ter tido algum conhecimento de sua existência, principalmente pela recriação que faz do suicídio. 
No palco, entra em cena um Mário gordo e desajeitado que cita versos do poema "Fim", retomando naturalmente o projeto mítico e narrativo iniciado por Pessoa: "Quando eu morrer, batam em latas, / Rompam aos saltos e aos pinotes”. E esse será mesmo o fim da vida que é encenada na peça. Há ainda outras referências a poemas de Sá-Carneiro: "esfinge gorda", "papa-açorda" que são figuras do poema "Aquele Outro", que, como "Fim" dão forma já a decadência moral e física da personagem Sá-Carneiro, na coletânea Últimos Poemas. Além disso, o fato de a peça começar exatamente pelo fim da poesia de Sá-Carneiro, enfatiza o aspecto terminativo dessa macronarrativa em que a vida só existe para dar lugar à morte.

Há também - e naturalmente - referências ao poema "7" (que constitui o mote central de toda a peça, já que no palco, ao lado de Mário (o “eu”), está, literalmente, o Outro) e aos Indícios de Oiro, com citações do poema "O Lord" que reforçam a decadência da personagem: "Lord que eu fui de Escócias doutra vida/ Hoje arrasta por esta a sua decadência, / Sem brilho e equipagens". O Outro, magro e alto, distinto e de fala baixa humilha-o a todo instante: “Tarefa quotidiana: dissolver as tuas banhas, Esfinge Gorda” (RÉGIO, 1969, p. 132).

Além do desprezo e da ofensa, o Outro é quem oferece a Mário uma taça, dizendo que nela há o que ele procura, o que vai torná-los iguais. Mário sorve-a e morre. Quando vai ao chão, entram palhaços e acrobatas que retiram o seu corpo de cena, realizando, cenicamente - ou cinicamente - o seu "Fim": "[Quando eu morrer] Chamem palhaços e acrobatas".

A convergência do discurso crítico com a criação artística, comum aos presencistas, com esse texto de Régio atinge o seu auge. O poeta Sá-Carneiro, retratado como gordo desajeitado, berrando ao Outro, confuso, perdido e triste, é aquele que se mata, teatralmente, buscando na morte o consolo que a vida não lhe deu: está aí registrada a culminância das diversas impressões sobre a obra de Sá-Carneiro, comuns a toda uma geração, nascidas, como dizíamos, sob a pena de Pessoa.

Essa imagem é repetida exaustivamente por uma crítica impressionista e, diríamos até mesmo, impressionada, que acaba por reduzir, em certa medida, a obra de Sá-Carneiro às angústias de um ("pobre”) menino ("ideal") pouco à vontade com seu corpo.

Em consonância com essa leitura, temos, entre outros, Berardinelli, mais uma vez nas primeiras páginas de sua Antologia (SÁ-CARNEIRO, 2015), em que afirma que a não aceitação de sua aparência física e a não realização emocional e profissional de Sá-Carneiro estão ligadas ao tema do fracasso que transparece em sua poesia. Ainda segundo essa grade de 
leitura, por exemplo, as "bocas esmagadas" do poema "Escavação", perdem o conteúdo semântico de erótico e sexual (negado, em todo caso, no poema), tornando-se metonímia do corpo "deformado, chaguento, condizen[te] com uma corporalidade grotesca" (ALMEIDA, 2007, p. 111).

Visto como "astro baço" (SILVA, 2012), "mago sem condão" (SÁ-CARNEIRO, 1996, p. 141), a Sá-Carneiro é dada uma voz poética que será, nessa direção, a de um corpo doente, espécie de "anjo caído" (AMORIM, 2004), metáfora que vai encontrar respaldo nas imagens das "asas" de "Dispersão" e de "Quase", compondo assim a curva descendente traçada em sua obra: "A grande ave dourada/ Bateu asas para os céus,/ Mas fechou-as saciada/ Ao ver que ganhava os céus" e "Para atingir, faltou-me um golpe de asa.../ Se ao menos eu permanecesse aquém" (SÁ-CARNEIRO, 1996). Nas diversas leituras de "A Queda" e d'A confissão de Lúcio, a inadequação - física e psíquica - será elevada à máxima potência conduzindo o sujeito a seu próprio aniquilamento - tanto ao ficcional quanto ao real, como se dirá.

\section{Teatro de luz: a sereia louca}

Eu fui o que quis: a minha obra representa zebradamente entre luas amarelas aquilo que eu quisera ser fisicamente: essa rapariga estrangeira de unhas polidas, doida e milionária...

Mário de Sá-Carneiro (2004, p. 190).

As imagens que recuperamos até aqui, especialmente na crítica, mas também na obra, parecem desenhar um corpo masculino, pouco afeito e pouco à vontade com a sua masculinidade, com o seu papel esperado diante do mundo. Nessa constelação de máscaras de Sá-Carneiro, o corpo é disforme, porque excessivo. É disforme, porque masculinamente excessivo: balofo, gordo, rei-lua, todos nomes masculinos que vão acentuar uma leitura do grotesco em sua obra.

Há, no entanto, na sua poesia e na sua narrativa, incluindo-se naturalmente as cartas, um outro Mário, que se estabelece e se forja em oposição ao primeiro, e em que a morte e o suicídio deixam de ser a tônica: esse é o Mário mulher, um poeta em franca metamorfose, que busca em um corpo outro o prazer e a vida, construindo uma imagerie feminina e sublime. Uma carta a Ricardo Teixeira é especialmente interessante quanto a essa questão. Diz SáCarneiro: "Eu também muitas vezes penso que sou é muito mulher" (SÁ-CARNEIRO, 1972, p. 46-47).

É também em uma carta a Fernando Pessoa, de 13 de julho de 1914, que se pode 
entrever essa metamorfose de Sá-Carneiro diretamente enunciada, metamorfose que permite a um só tempo a realização da obra e a realização da vida:

Vê: é toda esta futilidade, estas "mariquices" meu amigo que eu lamento numa grande dor - mas não em uma dor arrependida: Consegui, à força talvez só de o querer, obter o que ambicionava: Paris. Simplesmente era essa última maravilha, o fim, a Apoteose (e foi neste estado de espírito que eu escrevi o soneto "Apoteose" e assim o denominei) [...] O céu de minha obra não quero dizer que seja grande não sei se na verdade o será. Entretanto estou bem certo que é pesadamente dourado (talvez ouro falso, mas em todo caso dourado) com muitas luzes de cor, e lantejoulas, todas a girar, fumos polícromos, aromas, maquilhagens, lagos de água, dançarinas nuas, atrizes de Paris, salas de restaurantes, densos tapetes... E isso me basta. Passei na vida literária, creio, uma rapariga estrangeira, esguia, pintada, viciosa, com muito gosto para se vestir bizarramente - pelo menos e para dispor orquídeas em jarras misteriosas, em esquisitas talhas do Japão gulosa de morangos e champanhe, fumando ópios, debochada — ardendo loucamente. E se assim é, se não me engano: eu fui o que quis: a minha obra representa zebradamente entre luas amarelas aquilo que eu quisera ser fisicamente: essa rapariga estrangeira de unhas polidas, doida e milionária... (SÁ-CARNEIRO, 2004, p. 190, grifo nosso).

Preenchido de "mariquices", atinge com facilidade seu objetivo: "fui o que quis". O mesmo se dá n'A Confissão de Lúcio, por exemplo, em que a americana ruiva leva sua feminilidade a um nível extremo, a ponto de por fim à vida - realizando, em todo caso, uma obra:

Envolvia-a uma túnica branca, listada de amarelo. Cabelos soltos, loucamente. Jóias fantásticas nas mãos; e os pés descalços, constelados... Ai, como exprimir os seus passos silenciosos, úmidos, frios de cristal; o marulhar da sua carne ondeando; o álcool dos seus lábios que, num requinte, ela dourara - toda a harmonia esvaecida nos seus gestos; todo o horizonte difuso que o seu rodopiar suscitava, nevoadamente... Entretanto, ao fundo, numa ara misteriosa, o fogo ateara-se... Vício a vício a túnica lhe ia resvalando, até que, num êxtase abafado, soçobrou a seus pés... Ah! nesse momento, em face à maravilha que nos varou, ninguém pôde conter um grito de assombro... Quimérico e nu, o seu corpo sutilizado, erguia-se litúrgico entre mil cintilações irreais. Como os lábios, os bicos dos seios e o sexo estavam dourados - num ouro pálido, doentio. E toda ela serpenteava em misticismo escarlate a querer-se dar ao fogo... Mas o fogo repelia-a... Então, numa última perversidade, de novo tomou os véus e se ocultou, deixando apenas nu o sexo áureo - terrível flor de carne a estrebuchar agonias magentas... Vencedora, tudo foi lume sobre ela... (SÁ-CARNEIRO, 1991, p. 12).

Nos dois textos, na carta e na novela, têm-se claramente temas que serão frequentes em sua produção literária: a futilidade, as mariquices, as cores, os brilhos, enfim, toda a sua afetação, condensada na forma de uma "rapariga" cujos contornos são o do excesso: excesso de cor, excesso de prazeres, ou mesmo de pecados, como a gula e a luxúria, excesso, enfim, de uma feminilidade estereotipada, mundana, pecadora. Se no excesso do masculino, o poeta restava sempre aquém, incapaz de alçar voo, no excesso do feminino realizará - ou pelo menos projetará - muitos de seus desejos. 
E essa sua identidade feminina estabelecer-se-á tão fortemente que mesmo o seu interlocutor assim o reconhecerá:

como sobretudo lhe agradeço o lembrar-se de mim enternecidamente ao encomendar chapéus complicados para os costureiros célebres de Paris. Minhas fitas de cor, meus laços, minhas plumas, minhas filigranas. Tanto enleio perdido, tanta carícia desfeita! A Zoina, a grande Zoina sempre! Mas que lhe hei-de eu fazer?... (SÁ-CARNEIRO, 2004, p. 350, grifo nosso).

Aqui Sá-Carneiro agradece um comentário de Fernando Pessoa, no qual, mais uma vez, toda uma temática da afetação, do acessório, da futilidade, é construída dando ao poeta ares afetados e femininos (graças a figuras como "costureiro", "fitas", "laços", "plumas", que formam uma coerência temática singular de um dado "universo feminino").

Esse estereótipo feminino nas cartas (e também na sua obra) é análogo, ainda, a sua própria definição de Beleza, como podemos ver na carta, de 24 de agosto de 1915:

Mas o meu caso é bem mais terrível a certas horas: Para mim basta-me a beleza - e mesmo errada, fundamentalmente errada. Mas beleza: beleza retumbante de destaque e brilho, infinita de espelhos, convulsa de mil cores muito verniz e muito ouro: teatro de mágicas e apoteoses com rodas de fogo e corpos nus. Medo e sonambulismo, destrambelhos sardônicos cascalhando através de tudo. Foi esta a mira da minha Obra. Creio tê-la ganho às vezes (SÁ-CARNEIRO, 2004, p. 278, grifo nosso)

Eis a Beleza errada, viciosa, e doentia que está presente em todas as suas personagens femininas, em especial naquela construída no poema que acabou intitulado justamente como "Feminina".

O poema, chamado por Sá-Carneiro de "irritantíssimo", foi enviado por carta a Pessoa, em 16 de fevereiro de $1916^{10}$. Na carta - e não somente no poema - enuncia, mais uma vez, a sua transformação em figura feminina:

Feminina - que comecei ontem à noite, quando me roubaram o chapéu de chuva. Pano de amostra:

Eu queria ser mulher pra me poder estender

Ao lado dos meus amigos, nas banquettes dos cafés.

Eu queria ser mulher para poder estender

Pó de arroz pelo meu rosto, diante de todos, nos cafés.

Eu queria ser mulher pra não ter que pensar na vida

E conhecer muitos velhos a quem pedisse dinheiro -

Eu queria ser mulher para passar o dia inteiro

A falar de modas e a fazer "potins" — muito entretida.

Eu queria ser mulher para mexer nos meus seios

\footnotetext{
${ }^{10}$ É nessa carta também que envia o poema a que Fernando Pessoa dará o título de "Fim". De certa forma, uma identidade feminina completa é assim anunciada na mesma carta em que anuncia a forma de seu enterro. A assunção da feminilidade estaria de um lado e a sua morte anunciada, de outro.
} 
E aguçá-los ao espelho, antes de me deitar -

Eu queria ser mulher pra que me fossem bem estes enleios,

Que num homem, francamente, não se podem desculpar.

Eu queria ser mulher para ter muitos amantes

E enganá-los a todos - mesmo ao predileto -

Como eu gostava de enganar o meu amante loiro, o mais

esbelto,

Com um rapaz gordo e feio, de modos extravagantes...

Eu queria ser mulher para excitar quem me olhasse,

Eu queria ser mulher pra me poder recusar... (SÁ-CARNEIRO,

2004, p. 359-360, grifo nosso).

De "Feminina" a "pano de amostra" já se instaura toda uma construção figurativa feminina, mais uma vez, ligada à "costura" (pano de amostra), e por isso aos acessórios, às futilidades "que num homem não se podem desculpar". O motivo que leva o eu-lírico a tecer esse seu pano de amostra é singular: perdeu seu chapéu de chuva, peça do vestuário masculino, peça, enfim, identitária, identificadora, assim como o é o álcool para o vinho. Uma vez despido de seu chapéu, do papel masculino, pode então travestir-se, vestir-se, cobrir-se de acessórios e assumir finalmente, a sua identidade "feminina".

No poema, que reforça o estereótipo da futilidade de forma mais direta, a começar pelo "irritantíssimo" com o qual é definido, todos os fazeres do sujeito ali instaurado são formas de não-fazer, que não atuam diretamente sobre o mundo, sendo quase todos autorreflexivos, como "me poder estender", "estender pelo meu rosto", "mexer nos meus seios", e fazeres "vazios", que não alteram nenhum estado do sujeito "não ter que pensar", "falar de modas e a fazer "potins"” - que figurativamente representa um "fazer nada" -, "me fossem bem estes enleios". As suas não-ações, denotam, desse modo, o puro exibicionismo de um sujeito que, voltando-se para o seu próprio ser, constrói-se, ainda assim, em função do olhar do outro ("diante de todos", "para excitar quem me olhasse" e "pra me poder recusar") e não de seu próprio fazer. O sujeito, ao assumir sua nova identidade, passa assim, do tédio mortificante ao ócio reconfortante: o fazer nada fazendo bem a si. O grotesco que deveria estar escondido passando assim a sublime que deve ser exposto em público, "nos cafés"...

Temos ainda uma cisão significativa de uma das figuras do poema: o amante predileto e mesmo assim, traído. O eu "feminino" é, portanto, mentiroso, pois declara ter um amante predileto mas dele se desfaz facilmente (mas não tem): seu desejo maior é, na verdade, a própria traição exibicionista. Figurativamente constroem-se ainda duas figuras masculinas opostas: um sujeito loiro e esbelto (o Outro da peça de Régio) e um gordo e feio: diante do belo (alto), o eu "feminino" oferece-se ao feio (baixo). Desse modo, temos uma sórdida vingança, já que tudo o que de si é belo e feminino dá-se a si mesmo e não ao Outro. 
No nosso pequeno pano de amostra, o que queremos mostrar é que, se deixarmos de lado a temática que sempre foi a mais proeminente na leitura de Sá-Carneiro - o suicídio, a melancolia, a inadequação física - encontraremos na sua obra outra chave importante de leitura, outra miragem, como dissemos anteriormente, que permite melhor entrever a grandiosidade - e a modernidade - de sua escrita.

Se observamos a sua obra a partir, por exemplo, de quatro conjuntos de poemas: Dispersão e Indícios de Oiro, obras fechadas, construídas segundo a própria organização do autor, em vida; os Últimos poemas, segundo a organização a eles dada por Fernando Pessoa, conforme apontamos, e os quatro poemas autônomos: "Manucure", "Simplesmente", poema que deu origem ao poema "Partida", de Dispersão, "Feminina" e "Ah que te esquecesses sempre das horas", veremos que o tema do feminino, construído sobre bases como a sexualidade, a futilidade, o luxo e mesmo a morte, se destaca e nega o grotesco e a narrativa suicidaria tão frequente.

Em Dispersão, figuras femininas e sublimes se espalham pelos poemas "Partida", “Dispersão", "Estátua falsa”, “Como eu não possuo", "Além-tédio”. Em Indícios de Oiro, isso dá em "Salomé”, "Não", "Certa voz na noite, ruivamente...", "Bárbaro”, “A inegualável”, "Elegia", com as madeixas falsas e as suas dançarinas, "Sete canções de declínio, especialmente na segunda e a quinta canção, "Abrigo", que traz as tão frequentes unhas polidas, "Serradura" e "Último soneto". Dos "Últimos poemas", apenas "El-rei" traz uma imagem feminina, mas que é também da ordem do sublime: "Pra medir minha Zoina, aquém e além, / Só mística, de alada, esguia corça".

Em comum, todas as "feminilidades" de Sá-Carneiro têm algo de "Salomé":

\author{
Insónia roxa. A luz a virgular-se em mêdo, \\ Luz morta de luar, mais Alma do que a lua... \\ Ela dança, ela range. A carne, alcool de nua, \\ Alastra-se pra mim num espasmo de segrêdo... \\ Tudo é capricho ao seu redór, em sombras fátuas... \\ $\mathrm{O}$ arôma endoideceu, upou-se em côr, quebrou... \\ Tenho frio... Alabastro!... A minh'Alma parou... \\ E o seu corpo resvala a projectar estátuas... (SÁ-CARNEIRO, 1996, p. 74).
}

É justamente em Indícios de Oiro que a imagem feminina mais francamente se inscreverá. Segundo Helena Barras (1992), em seu estudo sobre o poema: exorcismo temporário da divisão (BARRAS, 1992, p. 51). 
O autosacrifício não é, pura e simplesmente nesse caso, o suicídio: é antes aquele gesto do qual já tratamos em que se tece a obra em detrimento da vida. Vale lembrar ainda que no primeiro verso do soneto "Salomé" encontramos a imagem "insônia roxa" e no primeiro verso do seu primeiro terceto, encontramos o verbo "nimbar". Essa combinação de figuras já é conhecida na poética de Sá-Carneiro, estando fixada a partir do primeiro poema de sua obra, "Partida": "Miragem roxa de nimbado encanto".

O roxo contrapõe-se aqui à pele branca (alabrastro). As figuras da pele feminina (ou afeminada) branca e da rouxidão da carne contundida, maculada, corrompida, serão recorrentes a marcar os corpos femininos. Por vezes, o roxo será vermelho ou ruivo, transformados em fogo e sangue, como em "Certa voz na noite, ruivamente...”, em que lemos "Leonina, ela arremessa a carne arroxeada" - o que mais uma vez nos faz pensar no gesto meteórico da americana ruiva, que cai morta diante de Lúcio. Em "Bárbaro" (SÁCARNEIRO, 1996, p. 91) temos, por exemplo:

\footnotetext{
Arqueia-me o delírio - e sufoco, esbracejo...

A luz enrijeceu zebrada em planos de aço...

A sangue se virgula e se desdobra o espaço...

Tudo é loucura já quanto em redor alvejo!...

Traço o manto e, num salto, entre uma luz que corta, Caio sobre a maldita.... Apunhalo-a em estertor...

— Não sei quem tenho aos pés: se a dançarina morta,

Ou a minha Alma só que me explodiu de cor...
}

O poema retoma a cena da morte da americana, assim como a ambivalência de Marta e Ricardo, aqui travestidos de dançarina morta e Alma.

Essa imagem de mulher marcada por um gesto de morte aparece também em algumas narrativas, como no conto "O fixador de instantes" (SÁ-CARNEIRO, 1995, p. 230), em que a personagem principal diz àquela que é sua vítima, que "Foi pra te rezar que de dourei de morte".

Esse ouro que reveste a morte feminina surge também em outros momentos, como o advérbio e o verbo que atravessam A Confissão de Lúcio: "evocando mordoradamente perfumes esfíngicos, luas amarelas, crepúsculos de roxidão. Beleza, perversidade, vício e doença” (SÁ-CARNEIRO, 1991, p. 6) e:

linda mulher loira, muito loira, alta, escultural - e a carne mordorada, dura, fugitiva. O seu olhar azul perdia-se de infinito, nostalgicamente. Tinha gestos nimbados e caminhava nuns passos leves, silenciosos — indecisos, mas rápidos. Um rosto formosíssimo, de uma beleza vigorosa, talhado em ouro. Mãos inquietantes de esguias e pálidas (SÁ-CARNEIRO, 1991, p. 26). 
O sucesso e a realização plena da sexualidade e da beleza dessas identidades femininas surgem na forma de vícios conquistados, da morte reconfigurada em ouro, das luas amarelas, das listas zebradas, das esfinges e dos perfumes: a miríade de figuras que recobre o feminino em Sá-Carneiro repete-se de maneira coesa e ordenada, das cartas, aos poemas e às narrativas. E essa estrutura é tão - ou mais - forte quanto aquela que permite a leitura do fracasso e do suicídio.

\title{
À guisa de conclusão
}

Ah, que te esquecesses sempre das horas / Polindo as unhas -/A impaciente das morbidezas louras/ Enquanto ao espelho te compunhas... (SÁ-CARNEIRO, 1996, p. $155)$.

E eu sempre na sensação de polir as minhas unhas / E de as pintar com um verniz parisiense, / Vou-me mais e mais enternecendo / Até chorar por Mim... (SÁCARNEIRO, 1996, p. 162).

Dieter Woll, em Realidade e idealidade na lírica de Sá-Carneiro (1968), trata da poesia de Portugal em termos de masculino e feminino. Curiosamente, ou talvez de modo muito astuto, diz o seguinte:

\begin{abstract}
A maior parte da poesia modernista em Portugal apresenta um tom acentuadamente duro, másculo. A sua atitude fundamental permanece firme e segura de si, por mais que o poeta oscile nos seus diversos estados de alma. A Sá-Carneiro falta, porém, uma atitude fundamental que assim se possa definir; não só se apresenta constantemente como joguete de forças superiores, mas surge, além disso, como joguete de estados psíquicos completamente heterogêneos. Nem o podemos conceber inteiramente como o super-homem irritado [...] nem como "pajem débil das ternuras de cetim" [...] (WOLL, 1968, p. 4-5).
\end{abstract}

Se deixarmos um de lado o mito tão bem elaborado ao longo de décadas, e passarmos a procurar na obra de Sá-Carneiro outros elementos que confirmar a sua inovação, encontraremos, para além da cisão entre o eu e o outro, a cisão entre o masculino e feminino, cisão que reconfigura profundamente o desejo e o corpo e que é, ainda hoje, absolutamente moderna.

Há, pois, na lírica de Sá-Carneiro, para além de um corpo grotesco e falho, um corpo metonímico, efêmero e translúcido, forjado por mãos delicadas, de unhas tratadas confirmando o gesto do cuidar de si, que impede que se diga que esse sujeito construído na sua obra rejeite apenas e definitivamente a imagem que projeta. Tem-se nos poemas, nas cartas e nas narrativas um corpo estranho, porque estrangeiro, porque outro, que se quer vicioso e guloso - por Paris e pelo mundo. Um corpo erotizado e à vontade, disposto a exporse nu, disposto a dar e receber prazer.

Se se deve buscar algum psicologismo na leitura da poesia de Sá-Carneiro, essa Anu. Lit., Florianópolis, v. 21, n. 2, p. 56-78, 2016. ISSNe 2175-7917 
deveria ser talvez razão para nela encontrar não a sua personalidade manifestada ou a sua biografia reinventada, não a sua persona, mas sim uma leitura do humano, das dúvidas e das suas facetas mais ocultas.

$\mathrm{Na}$ esteira da reflexão de Woll, deveríamos olhar mais para a poesia de Sá-Carneiro como quem olha para a ânima (JUNG, 1991), pois é aí, nesse seu corpo feminino que se despe e que deseja, que está sua poesia. Essa seria enfim uma poesia de Alma, de uma alma que é "A Rainha" que, mesmo "velha", quer ainda e sempre ser "Princesa nua, / E debochada e linda..." (SÁ-CARNEIRO, 1996, p. 78).

\section{Referências}

ALMEIDA, Rogério Caetano de. O corpo grotesco como elemento de construção poética nas obras de Augusto dos Anjos, Mário de Sá-Carneiro e Ramón López Velarde. 2007. 239 f. Dissertação (Mestrado em Estudos Comparados de Literatura e Língua Portuguesa). Faculdade de Filosofia e Ciências Humanas da USP, São Paulo, 2007.

AMORIM, Isabelle Regina de. A intertextualidade como mecanismo de composição da peça de José Régio. Terra roxa e outras terras. Revista de Estudos Literários, Londrina, v. 4, p. 926, 2004.

BARRAS, Helena. Salomé de Mário de Sá-Carneiro. Taíra. Revue du centre de recherche et d'études lusophones et intertropicales. N. 4, 1992, Université Stendhal - Grenoble III, 1992, p. 37-56.

CALCANHOTO, Adriana. Público. Faixa 7, BMG, 2000, 1 CD-ROM.

CASTEX, François. Les problèmes posés par une édition critique de l'œuvre de Mário de SáCarneiro. Actes du Colloque Critique textuelle portugaise. Paris: Fondation Calouste Gulbenkian-Centre Culturel Portugais, 1986, p. 329-334.

MONTEIRO, Adolfo Casais. Considerações Pessoais. Coimbra: Imprensa da Universidade de Coimbra, 1933.

DOUBROVSKY, Serge. Fils. Paris: Galilée, 1977.

FERREIRA, Ermelinda Maria Araújo. Mário de Sá-Carneiro: doença e criatividade. Veredas, Coimbra, n. 16, 2011. Disponível em: < http://hdl.handle.net/10316.2/34513>. Acesso em: 14 jun. 2016.

FERREIRA, Maria Ema Tarracha. Introdução. In: SÁ-CARNEIRO, Mário de. Poesias. Lisboa: Ulisséia, 2000. p. 5-170.

JUNG, Emma. Animus e anima. Trad. de Dante Pignatari. São Paulo: Editora Cultrix, 1991.

MARTINS, Fernando Cabral. O modernismo em Mário de Sá-Carneiro. Lisboa: Editorial Estampa, 1997. 
PAIXÃO, Fernando. Narciso em sacrifício. A poética de Mário de Sá-Carneiro. Cotia (SP): Ateliê Editorial, 2003.

PESSOA, Fernando. Cartas de Fernando Pessoa a João Gaspar Simões. (Introdução, apêndice e notas do destinatário.) Lisboa: Imprensa Nacional - Casa da Moeda, 1982.

. Livro do Desassossego. v. I. Organização e fixação de inéditos de Teresa Sobral Cunha. Coimbra: Presença, 1990.

. Textos de Crítica e de Intervenção. Lisboa: Ática, 1980.

QUADROS, António. Os Modernos de Ontem e de Hoje. Lisboa: Portugália, 1947.

RÉGIO, José. Mário ou Eu-Próprio - o Outro. In: RÉGIO, José. Três peças em um acto. 2. ed. Lisboa: Portugália, 1969.

RIBEIRO, Wagner. Antologia Luso-Brasileira. São Paulo: Coleção FTD, 1964.

SÁ-CARNEIRO, Mário de. A confissão de Lúcio. Rio de Janeiro: Ediouro, 1991.

- Antologia. Organização, apresentação e ensaios de Cleonice Berardinelli. Rio de Janeiro: Edições de Janeiro, 2015.

Cartas inéditas de Mário de Sá-Carneiro. Comentadas por François Castex. Revista Colóquio Letras, n. 7. Maio de 1972, p. 40-49.

Correspondência com Fernando Pessoa. Edição de Teresa Sobral Cunha. São Paulo: Companhia das Letras, 2004.

Obra completa. Rio de Janeiro: Nova Aguilar, 1995.

Poemas completos. Edição, prefácio e notas de Fernando Cabral Martins. Lisboa: Assírio \& Alvim, 1996.

SCHWARTZMANN, Matheus Nogueira. Cartas marcadas: prática epistolar e formas de vida na correspondência de Mário de Sá-Carneiro. 2009. 293 p. Tese. (Doutorado em Linguística e Língua Portuguesa) - Faculdade de Ciência e Letras de Araraquara, Universidade Estadual Paulista, Araraquara.

Um rei incoerente: o percurso do sujeito sá-carneiriano em Dispersão. 2005. 245 p. Dissertação (Mestrado em Letras). Faculdade de Ciência e Letras de Araraquara, Universidade Estadual Paulista, Araraquara.

SILVA, Josebede Angélica Guilherme da. O astro baço. Mário de Sá-Carneiro sob o Signo de Saturno. 2012. 169 f. Dissertação (Teoria da Literatura). Universidade Federal de Pernambuco, Recife, 2012.

SIMÕES, João Gaspar. O mistério da poesia. Porto: Editorial Inova, 1971.

SOUZA NETO, Zeno Germano de. A escrita de si: o discurso literário e o inconsciente em $A$ Confissão de Lúcio. 99 p. Dissertação. (Mestrado em Estudos Literários). Fundação Universidade Federal de Rondônia, Porto Velho, 2015. 
WOLL, Dieter. Realidade e idealidade na lírica de Sá-Carneiro. Delfos: Lisboa, 1968.

[Recebido em 28 de setembro de 2016 e aceito para publicação em $1^{\circ}$ de outubro de 2016]

Mário de Sá-Carneiro: evidence of a myth, evidence of a body

Abstract: This paper aims to propose an aerial reading of some elements found in Mário de Sá-Carneiro's work, by pursuing to point, firstly, how its mythical dimension, cultivated since the first editions of his work, deeply set the reading done of it. In this regard, we will approach his suicide, retaken and reaffirmed by names, such as Fernando Pessoa, José Régio, Casais Monteiro, for instance, and how this theme contributed to the myth crystallization. In a second moment, taking into consideration certain themes and figures that can be seized of SáCarneiro's texts, we will show other reading paths, searching in poems, letters and some of his narratives elements that will allow to glimpse in his writing the presence of his body. And it is this body description, which proposes again concepts of feminine and masculine, that seems to be for us what we should take as innovative in his poetry, in the way it would be exactly one of his evidence of modernity.

Keywords: Mário de Sá-Carneiro. Myth. Femininity. Body.

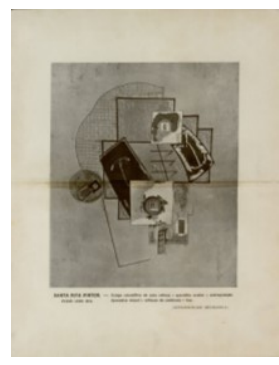

